\title{
Is serum iron responsive protein-2 level associated with pulmonary functions and frequent exacerbator phenotype in COPD?
}

\author{
Nilüfer Aylin ACET \\ ÖZTÜRK ${ }^{1}$ (ID) \\ Aslı GÖREK \\ DILEKTAŞLI $^{1}$ (ID) \\ Ezgi DEMiRDÖĞEN ${ }^{\mathbf{1}}$ (ID) \\ Funda $\operatorname{COŞKUN}^{1}$ (ID) \\ Ahmet URSAVAŞ ${ }^{1}($ ID) \\ Mehmet KARADAĞ ${ }^{\mathbf{1}}$ (ID) \\ Esra KUNT \\ UZASLAN $^{1}$ (ID)
}

Cite this article as: Acet Öztürk NA, Görek Dilektaşılı A, Demirdöğen $E$, Coşkun F, Ursavaş $A$, Karadağ $M$, et al. Is serum iron responsive protein-2 level associated with pulmonary functions and frequent exacerbator phenotype in COPD? Tuberk Toraks 2020;68(3):252-259.

\section{Yazışma Adresi (Address for Correspondence)}

\section{Dr. Aslı GÖREK DILEKTAŞLI}

Uludağ Üniversitesi Tıp Fakültesi,

Göğüs Hastalıkları Anabilim Dalı,

BURSA - TÜRKIYE

e-mail: asligorekd@gmail.com

CCopyright 2020 by Tuberculosis and Thorax.

Available on-line at www.tuberktoraks.org.com
${ }^{1}$ Department of Chest Diseases, Faculty of Medicine, Uludag University, Bursa, Turkey

${ }^{1}$ Uludağ Üniversitesi Tıp Fakültesi, Göğüs Hastalıkları Anabilim Dalı, Bursa, Türkiye

\begin{abstract}
Is serum iron responsive protein-2 level associated with pulmonary functions and frequent exacerbator phenotype in COPD?

Introduction: Chronic Obstructive Pulmonary Disease (COPD) exacerbations contribute to the overall severity in individual patients because they are associated with airway inflammation, pulmonary function loss, decreased quality of life and increased mortality. Although, identifying frequent exacerbator patients is important due to severe outcomes associated with frequent exacerbator phenotype in COPD patients there is no single biomarker which can differentiate this phenotype. Iron responding protein-2 (IRP2) is the protein product of IREB2 gene, which is a COPD susceptibility gene that regulates cellular iron homeostasis and has a key role in hypoxic conditions. Previous research indicates that IREB2 expression in lung tissue is associated with spirometric measurements and emphysema in COPD. In this study, our aim was to investigate whether serum IRP2 levels were associated with frequent exacerbator phenotype, to evaluate whether IRP2 levels in serum are associated with pulmonary functions and selected systemic inflammation biomarkers.
\end{abstract}

Materials and Methods: Designed as a single tertiary care center based, crosssectional study, included high risk (GOLD C, D) COPD patients who admitted to outpatient clinic consecutively between December 2015 and July 2016.

Results: The study included 80 COPD patients. Serum IRP2 levels were negatively correlated with $F E V, m l(r=-0.25, p=0.02)$ and body weight $(r=-0.35$, $p=0.002$ ) but not with markers of systemic inflammation. COPD patients with at least one exacerbation history in the last year tended to have higher IRP2 levels than patients without any exacerbation [12.3 (IQR 25-75: 10.417.1) vs 10.5 (IQR 25-75: 8.8-18.5), $p=0.06$ ].

Conclusion: Serum IRP2 level is significantly correlated with FEV ${ }_{1} \mathrm{~mL}$ but not with FEV $\%$ predicted and cannot be used to differentiate frequent exacer- 
bator patients. Although IREB2 gene expressions in lung tissue and bronchoalveolar lavage results have significant associations with emphysema and $F E V_{1} / F V C, F E V_{1}$ \% predicted in COPD patients, our results suggests serum IRP2 level is not as promising.

Key words: Iron responsive protein-2; COPD; frequent exacerbator phenotype

\section{ÖZ}

\section{Serum iron responsive protein-2 düzeyinin $\mathrm{KOAH}^{\prime} \mathbf{l}$ olgularda solunum fonksiyonları ve sık alevlenme fenotipi ile ilişkisi}

Giriș: Kronik obstrüktif akciğer hastalığı (KOAH) alevlenmeleri, hava yolu inflamasyonu, solunum fonksiyonlarında kayıp, kötü yaşam kalitesi ve artmış mortalite ile ilişkisi dolayısıyla hastalık şiddeti ile direkt ilişkilidir. Sık alevlenme fenotipine sahip olguların belirlenmesi önem arz etmekle beraber bu ayırımı sağlayan tek bir biyobelirteç henüz saptanmamıştır. Iron respionsive protein (IRP2), hücresel demir hemostazında görevli olan ve hipoksik koşullarda anahtar roller olan KOAH duyarlılık genlerinden IREB2 geninin protein ürünüdür. Akciğer dokusunda IREB2 ekspresyonu, KOAH olgularında amfizem yaygınlığı ve spirometrik ölçümlerle ilişkilendirilmiştir. Çalışmamızın birincil amacı serum IRP2 düzeyinin sık alevlenen KOAH fenotipini belirlemede rolü olup ikincil amaçları serum IRP2 düzeyi ile akciğer fonksiyonları ve sistemik inflamatuvar biyobelirteçler arasında ilişkinin değerlendirilmesidir.

Materyal ve Metod: Tek merkezli kesitsel bir çalışma olarak planlanmıştır. Aralık 2015 ile Haziran 2016 tarihleri arasında üçüncü basamak hastanemizin gögüs hastalıkları polikliniğine başvuran yüksek alevlenme riski olan (grup C ve D) KOAH olguları sırasılla çalışmaya dahil edilmiştir.

Bulgular: Çalışma popülasyonu 80 hastadan oluşmaktadır. Serum IRP2 düzeyi $F E V_{1} m l(r=-0.25, p=0.02)$ ve vücut ağırlığı $(r=-0.35$, $p=0.002$ ) ile ters orantılı olup sistemik inflamasyon belirteçleri ile korelasyon göstermemektedir. Serum IRP2 ölçümleri, geçmiş bir yıl içinde en az bir alevlenme öyküsü olan KOAH olgularında hiç alevlenme geçirmeyen KOAH olgularına göre daha yüksek olma eğilimindedir [12.3 (IQR 25-75: 10.4-17.19 vs 10.5 (IQR 25-75: 8.8-18.5), p=0.06]. Sık alevlenme fenotipine sahip olan ve olmayan olguların serum IRP2 düzeyleri sırasıyla; 12.3 [IQR 25-75: 10.1-18] ve 11.3 [IQR 25-75: 8.9-17.3] olarak ölçülmüştür.

Sonuç: Serum IRP2 düzeyi FEV $1 \mathrm{ml}$ ile korele olmakla beraber FEV \% obeklenen değeri ile istatistiksel anlamlı korelasyon göstermemektedir. Buna ek oalrak sık alevlenme fenotipinin ayırımı için de kullanılmamaktadır. Akciğer dokusunda ve bronkoalveoler lavaj örneklerinde IREB2 gen ekspresyonu ile amfizem, FEV /FVC, FEV 1 \% beklenen değerleri arasında anlamlı ilişki izlenmiş olsa da serum IRP2 düzeylerinde benzer sonuçlar elde edilememiştir.

Anahtar kelimeler: Iron responsive protein-2; KOAH; sık alevlenme fenotipi

\section{INTRODUCTION}

Chronic Obstructive Pulmonary Disease (COPD) is characterized by persistent airflow limitation that is usually progressive and associated with an enhanced chronic inflammatory response in the airways and the lung to noxious particles or gases. Exacerbations contribute to the overall severity in COPD patients (1) because they are associated with amplified airway inflammation, pulmonary function loss, decreased quality of life and increased mortality (2). Patients with high risk of exacerbation have worse spirometry measures, a history of previous exacerbation, gastro-esophageal reflux and higher white blood cell counts (3). Frequent exacerbator patients are defined by having at least two exacerbations per year. Frequent exacerbators have more respiratory symptoms, worse health-related quality of life, less daily activities and more severe airflow limitation. Despite its clinical relevance, there is no single biomarker which can differentiate frequent exacerbator patients from infrequent exacerbators.

While there are many genome-wide association studies in COPD patients, there are few gene expression and serum protein studies. Iron responding protein-2 (IRP2) is the protein product of IREB2 gene, which is a COPD susceptibility gene that regulates cellular iron homeostasis and has a key role in hypoxic conditions (4). In COPD patients IRP2 gene is over expressed in emphysematous lung tissue (5). Also, studies aiming to determine the relation between iron accumulation and COPD, using lung tissue and BAL samples, showed a relation between IREB2 gene expression levels and $\mathrm{FEV}_{1}$ and $\mathrm{FEV}_{1} / \mathrm{FVC}$ (6). In addition to its association with pulmonary functions, IREB2 gene expression was associated with exacerbation in asthmatic patients. Exposure to house dust mites in atopic asthmatic patients resulted in significant difference in expression IREB2 gene in serum samples (7). Despite its promising role in COPD pathogenesis, currently there is no study that evaluates associations of IRP2 levels in serum with pulmonary functions, symptoms and exacerbation frequency in COPD patients.

Our primary aim was to investigate whether serum IRP2 levels was associated with frequent exacerbation phenotype in severe COPD patients. Our secondary aim was to evaluate association of serum IRP2 
levels with pulmonary function tests and selected systemic inflammation biomarkers.

\section{MATERIALS and METHODS}

\section{Study Setting and Study Population}

This study was designed as a single tertiary care center based cross-sectional study. Patients with a COPD diagnosis over 40 years old, with at least 10 pack. yrs.-1 smoking history with a clinical COPD diagnosis were enrolled. The study included high risk COPD patients for exacerbations according to combined COPD assessment (referred as C and D categories) who were admitted to outpatient clinic consecutively between December 2015 and July 2016 (1). The exclusion criteria were having history of exacerbation or oral glucocorticoid use or pneumonia in the last month, lung cancer and asthma.

The institutional ethical committee approved the study protocol and informed consent was obtained from the patients.

\section{Definitions}

Airflow limitation is measured by spirometry and post-bronchodilator $\mathrm{FEV}_{1} / \mathrm{FVC}<70 \%$ confirmed the presence of COPD (1). Combined COPD assessment groups patients according to spirometric classification, symptom evaluation and exacerbation risk. According to combined COPD assessment, patients with high risk for exacerbation were classified as group $C$ and $D$, due to severe airflow limitation $\left(\mathrm{FEV}_{1}<50 \%\right.$ ) or $\geq 2$ exacerbation or $\geq 1$ severe exacerbation leading to hospitalization. Group C and D were discriminated by symptom severity using CAT score or mMRC (1).

COPD exacerbation and frequent exacerbations were defined as an acute event characterized by a worsening of the patient's respiratory symptoms that is beyond normal variations that leads to a change in medication and having two or more exacerbation per year, respectively (1). Patients were asked to report the number of COPD exacerbations and treatment change or hospitalization history in the previous 12 months. This data was then confirmed from the National Prescription Database (MEDULA) and hospital database if available. Patients with two or more COPD exacerbation history were classified as frequent exacerbator.

\section{Study Procedures}

Demographic variables, anthropometric measurements and laboratory findings were recorded. COPD
Assessment Test (CAT) was used for symptom assessment of the patients face to face by using validated Turkish version of CAT (8). CAT is an 8 item questionnaire, with higher scores indicating worse health status impairment due to COPD. COPD diagnosis was confirmed by spirometry and post-bronchodilator spirometric values were recorded. Spirometry was performed according to the ATS/ERS recommendations for standardization of lung function testing (9) by the same technician using Vmax Encore System (Sensormedics, Viasys, Yorba Linda, CA, USA).

Blood samples were taken by venipuncture from the patients in the outpatient clinic. Serum samples were analyzed by Human IRP2 ELISA kit (SunRed, China) which uses a double-antibody sandwich enzymelinked immunosorbent assay (ELISA) to assay the level of IRP2 levels in human serum, blood plasma, and other related tissue liquid samples.

\section{Statistical Analysis}

Data were analyzed using Statistical Package for Social Sciences (SPPS) version 22 (IBM Corp., Armonk, NY, USA). The variables were analyzed for normally distribution by using visual (histograms, probability plots) and analytical methods (Kolmogorov-simirnov/Shapiro-Wilk's test). Means and standard deviations were reported for normally distributed continuous data, and medians and inter-quartile ranges (ICR) for non-normally distributed continuous data. Correlation between non-normally distributed data were calculated by Spearman test. Mann-Whitney $U$ test was used to compare non-normally distributed variables. A multiple linear regression model was used to identify independent predictors of serum IRP-2 level. An overall 5\% type-I error level was used to infer statistical significance.

\section{RESULTS}

COPD patients admitted to the outpatient clinic were assessed for eligibility and 80 high risk COPD patients (78 male, 2 female) were consecutively included in the study. Patient recruitment and study flow is shown in Figure 1. The mean age of study group was $64 \pm 10$ years. Clinical characteristics of the study patients are shown in Table 1.

Frequent exacerbator (FE) patients had comparable age, sex, BMI and smoking status with infrequent exacerbator patients. However FE patients had more severe spirometric impairment and more pronounced symptoms assessed by CAT (Table 2). Serum IRP2 


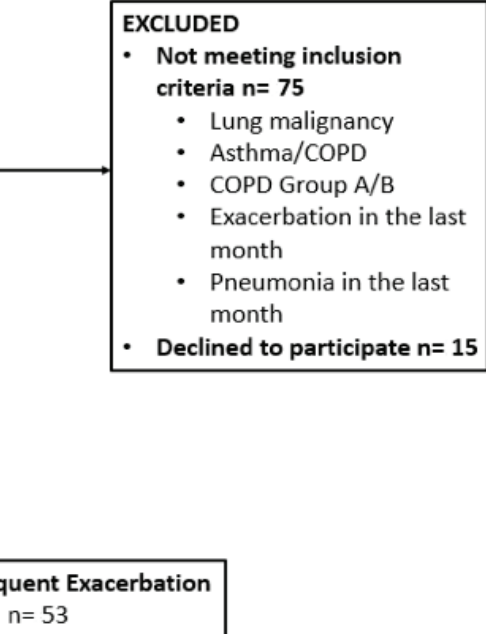

Figure 1. Consort flow diagram of the study.

\section{Table 1. The characteristics of patients* $(n=80)$}

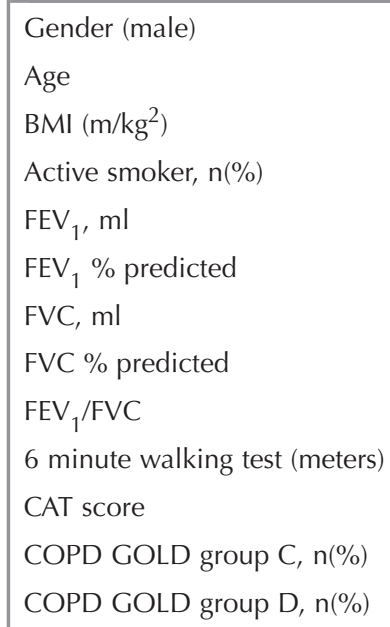


Is serum iron responsive protein-2 level associated with pulmonary functions and frequent exacerbator phenotype in COPD?

Table 2. Differences between frequent exacerbator and infrequent exacerbator patients

\begin{tabular}{|c|c|c|c|}
\hline & $\begin{array}{l}\text { Frequent exacerbator } \\
\qquad(n=27)\end{array}$ & $\begin{array}{l}\text { Infrequent exacerbator } \\
\qquad(n=53)\end{array}$ & $\mathbf{p}$ \\
\hline Gender (male), n (\%) & $26(96.2)$ & $52(98)$ & $>0.999$ \\
\hline Age & $66.4 \pm 10.7$ & $63.9 \pm 8.6$ & 0.23 \\
\hline $\mathrm{BMI}\left(\mathrm{m} / \mathrm{kg}^{2}\right)$ & $26.6 \pm 6.2$ & $27.9 \pm 6.6$ & 0.52 \\
\hline Active smoker, n (\%) & $2(7.4)$ & $11(20.7)$ & 0.20 \\
\hline $\mathrm{FEV}_{1} \mathrm{ml}$ & $804 \pm 289$ & $1076 \pm 329$ & 0.0001 \\
\hline $\mathrm{FEV}_{1} \%$ predicted & $30.7 \pm 11.1$ & $39 \pm 10$ & 0.002 \\
\hline FVC ml & $1190 \pm 400$ & $1572 \pm 495$ & 0.0001 \\
\hline FVC $\%$ predicted & $35.4 \pm 12.3$ & $44.8 \pm 12.6$ & 0.002 \\
\hline $\mathrm{FEV}_{1} / \mathrm{FVC}$ & $67(9.95)$ & $68(5)$ & 0.19 \\
\hline 6 minute walking test $(\mathrm{m})$ & $188.7 \pm 73.3$ & $207.7 \pm 79.8$ & 0.40 \\
\hline CAT score & $20(11-28)$ & $13(9-19)$ & 0.05 \\
\hline Number of comorbidities & $1(0-2)$ & $1(0-2)$ & 0.55 \\
\hline Having at least one comorbidity (n, \%) & $16(59.2)$ & $35(66)$ & 0.60 \\
\hline
\end{tabular}

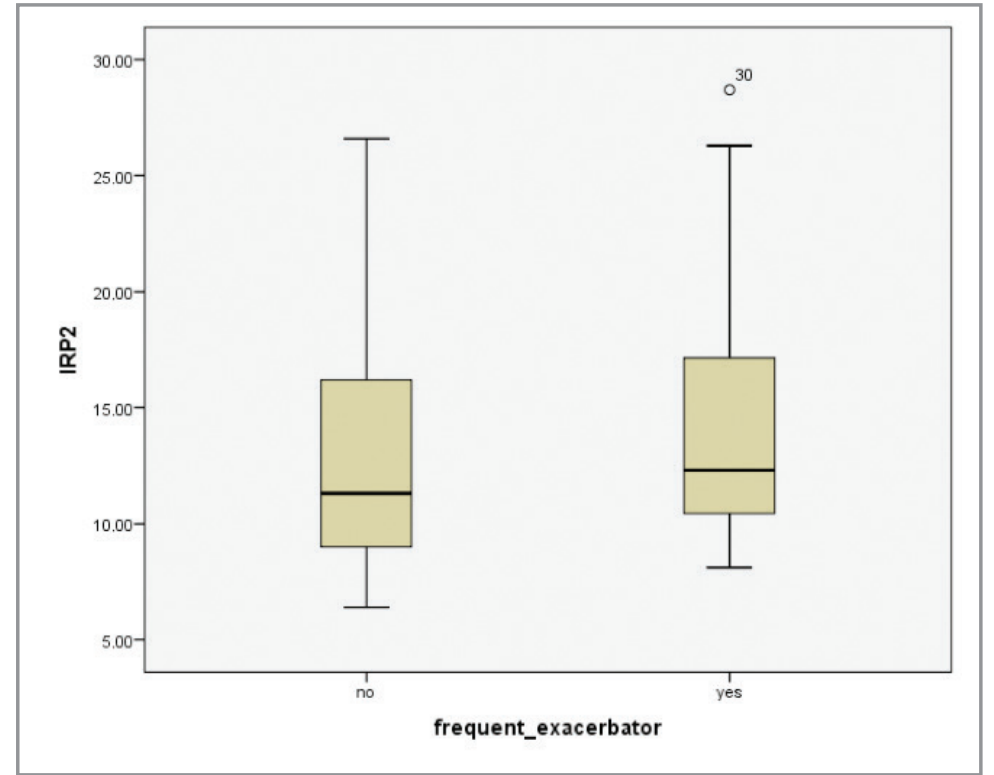

Figure 2. Serum-IRP2 levels in frequent exacerbator [12.3 (10.1-18)] and infrequent exacerbator patients [11.3 (8.9-17.3)].

levels were $12.3(10.1-18) \mu \mathrm{g} / \mathrm{mL}$ and $11.3(8.9-17.3)$ $\mathrm{ng} / \mathrm{mL}$ in $\mathrm{FE}$ and infrequent exacerbator patients $(\mathrm{p}=$ 0.37) (Figure 2). Serum IRP2 level was not correlated with number of total exacerbations $(p=0.09)$ or number of exacerbations leading to hospitalization $(p=$ 0.4). However patients with at least one exacerbation history tended to have higher IRP2 levels than patients without any exacerbation [10.5 (8.8 - 18.5) $\mu \mathrm{g} / \mathrm{mL}$ vs $12.3(10.4-17.1) \mu \mathrm{g} / \mathrm{mL}, \mathrm{p}=0.06]$.
Correlation of blood IRP2 levels with secondary outcomes were analyzed by Spearman test (Table 3). IRP2 levels were negatively correlated with $\mathrm{FEV}_{1} \mathrm{ml}$ $(r=-0.257, p=0.02)$. There was a negative correlation between IRP2 levels and weight $(r=-0.358, p=$ $0.002), \mathrm{BMI}(r=-338, p=0.003)$. IRP-2 level was not correlated with serum systemic inflammation markers such as white blood cell count $(p=0.7)$, lymphocyte count $(p=0.14)$, neutrophil count $(p=0.4)$, C 
Table 3. Correlations of IRP2 level

\begin{tabular}{|c|c|c|}
\hline & $\mathbf{r}$ & p \\
\hline Total number of exacerbation in last year & 0.18 & 0.09 \\
\hline Number of exacerbations leading to hospitalization in last year & 0.09 & 0.40 \\
\hline $\mathrm{FEV}_{1} / \mathrm{FVC}$ & -0.15 & 0.15 \\
\hline $\mathrm{FEV}_{1} \%$ predicted & -0.18 & 0.12 \\
\hline $\mathrm{FEV}_{1} \mathrm{ml}$ & -0.25 & 0.02 \\
\hline FVC $\%$ predicted & -0.17 & 0.12 \\
\hline FVC ml & -0.21 & 0.05 \\
\hline CRP & -0.31 & 0.78 \\
\hline Procalcitonin & 0.03 & 0.74 \\
\hline Erythrocyte sedimentation rate & 0.05 & 0.63 \\
\hline White blood cell count & 0.04 & 0.70 \\
\hline Lymphocyte count & -0.16 & 0.14 \\
\hline Neutrophil count & 0.08 & 0.40 \\
\hline Weight & -0.35 & 0.002 \\
\hline BMI & -0.33 & 0.003 \\
\hline
\end{tabular}

Table 4. Multiple linear regression model for serum IRP-2 levels

\begin{tabular}{|lccc|}
\hline Variable & Coefficient $\mathbf{( 9 5} \% \mathbf{C l})$ & p & 0.03 \\
\hline Weight & -0.156 & -0.007 & 0.16 \\
FEV $_{1}$ ml & -0.007 & 0.001 & 0.54 \\
FEV $_{1}$ /FVC & -0.441 & 0.236 & 0.72 \\
Total exacerbation number & -1.232 & 0.866 & \\
\hline
\end{tabular}

reactive protein $(p=0.78)$, procalcitonin $(p=0.74)$ and erythrocyte sedimentation rate $(p=0.63)$. Multiple linear regression model for IRP-2 identified weight as an independent predictor $(p=0.03)$ (Table 4).

\section{DISCUSSION}

Protein product of IREB2 is IRP2, a RNA binging protein, has an important role in maintaining cellular iron metabolism. IRP2 protein is localized especially at the ciliary surface of airway epithelial cells and endothelial cells, immune cells (macrophages) (5). Prior studies suggested iron imbalance has a role in pulmonary inflammation via oxidative injury and iron induced autophagy in epithelial and endothelial cells $(10,11)$.

IREB2 single nucleotide polymorphism (SNP) variants were associated with COPD, independent of smok- ing behavior $(12,13)$. IREB2 expression in bronchoalveolar lavage samples tended to be higher in COPD patients but wasn't statistically significant (6). IREB2 mRNA and IRP2 protein levels are higher in emphysematous lung tissue (5) and IREB2 gene is even associated with emphysema patterns (14). This results can be explained by oxidative stress caused by disturbance in iron homeostasis.

Iron homeostasis especially extracellular iron is important in immunity and microbiota (15). In light of these studies it is hypothesized that dysregulation of iron balance in COPD patients may change the microbiota, predispose them to colonization and triggering exacerbations (16). In addition to that, IREB2 gene expression is elevated in asthmatic patients when exposed to dermatophagoides pteronyssinus allergen 1 (7). However our study suggests that IRP2 protein levels are higher in frequent exac- 
erbators compared to infrequent exacerbators without statistical significance. Although IRP2 levels are correlated with the number of total exacerbations and number of exacerbations leading to hospitalization it also didn't reach statistical significance. However linear regression indicates only weight is associated with IRP2 after adjusting pulmonary function test and number of total exacerbation.

We demonstrated in our study that blood IRP2 levels are correlated with $\mathrm{FEV}_{1}$, which is in accordance with gene SPN and genome wide association studies. In a recent meta-analysis consist of 13532 participant (6260 COPD patients) from COPDGene, ECLIPSE and GenKOLS cohorts, IREB2 gene SPN was found to be associated with both $\mathrm{FEV}_{1} / \mathrm{FVC}$ and $\mathrm{FEV}_{1}(17)$. De Meo et al used data from various cohorts, consisting 1648 COPD patient, 472 smoker, 2807 relatives of COPD patients, to identify IREB2 as a COPD susceptibility gene and showed IREB2 SPN is associated with both pre- and post-bronchodilator $\mathrm{FEV}_{1}$ (5).

\section{Strengths and Limitations}

This is the first study evaluating serum IRP2 levels in COPD population in order to discriminate frequent exacerbator phenotype.

Power and sample size calculations were done according to IREB2 gene expression differences in asthma exacerbation due to lack of previous studies about serum levels of IRP2. Because of the difference between the referred study group and our study population, our sample size could be underpowered to detect a real difference or a real association of IRP2 with clinical or laboratory parameters.

\section{CONCLUSION}

We aimed to evaluate serum levels of a protein product of a known COPD susceptibility gene because serum samples are easier to obtain and cheaper to evaluate. Our results showed serum IRP2 level is significantly correlated with $\mathrm{FEV}_{1} \mathrm{~mL}$ but not with $\mathrm{FEV}_{1} \%$ predicted and cannot be used to differentiate frequent exacerbator patients. Although IREB2 gene expressions in lung tissue and bronchoalveolar lavage results have significant associations with emphysema and $\mathrm{FEV}_{1}$ / $\mathrm{FVC}, \mathrm{FEV}_{1} \%$ predicted in COPD patients, our results suggests serum IRP2 level is not as promising.

Ethics Committee Approval: The approval for this study was obtained from Bursa Uludağ University Faculty of Medicine Ethics Committee (Decision no: 2015-13/7 Date: 30.06.2015)

\section{CONFLICT of INTEREST}

There is no conflict of interest related to this study.

\section{AUTHORSHIP CONTRIBUTIONS}

Concept/Design: NAAÖ, AGD, ED, FC, AU, EU

Analysis/Interpretation: NAAÖ, AGD, EU

Data Acquisition: NAAÖ, AGD, EU

Writting: NAAÖ, AGD, ED, FC, AU, EU

Critical Revision: NAAÖ, AGD, ED, FC, AU, EU

Final Approval: NAAÖ, AGD, ED, FC, AU, EU

\section{REFERENCES}

1. http://goldcopd.org/global-strategy-diagnosis-management-prevention-copd-2016/

2. Donaldson GC, Müllerova H, Locantore N, Hurst JR, Calverley PM, Vestbo J, et al. Factors associated with change in exacerbation frequency in COPD. Respir Res 2013; 14: 79 .

3. Qureshi H, Sharafkhaneh A, Hanania NA. Chronic obstructive pulmonary disease exacerbations: latest evidence and clinical implications. Ther Adv Chronic Dis 2014; 5(5): 212-27.

4. Khiroya H, Turner AM. The role of iron in pulmonary pathology. Multidiscip Respir Med 2015; 10: 34.

5. DeMeo DL, Mariani T, Bhattacharya S, Srisuma S, Lange C, Litonjua $A$, et al. Integration of genomic and genetic approaches implicates IREB2 as a COPD susceptibility gene. Am J Hum Genet 2009; 85(4): 493-502.

6. Philippot Q, Deslée G, Adair-Kirk TL, Woods JC, Byers D, Conradi $S$, et al. Increased iron sequestration in alveolar macrophages in chronic obstructive pulmonary disease. PLoS One 2014; 9(5): e96285.

7. Pniewska E, Sokolowska M, Kupryś-Lipińska I, Kacprzak $D$, Kuna P, Pawliczak R. Exacerbating factors induce different gene expression profiles in peripheral blood mononuclear cells from asthmatics, patients with chronic obstructive pulmonary disease and healthy subjects. Int Arch Allergy Immunol 2014; 165(4): 229-43.

8. Yorgancıoğlu A, Polatı M, Aydemir Ö, Yılmaz Demirci N, Kırkıl G, Naycı Atış S, et al. Reliability and validity of Turkish version of COPD assessment test. Tuberk Toraks 2012; 60(4): 314-20.

9. Miller MR, Hankinson J, Brusasco V, Burgos F, Casaburi R, Coates A, et al. Standardisation of spirometry. Eur Respir J 2005; 26(2): 319-38.

10. O'Brien-Ladner AR, Nelson SR, Murphy WJ, Blumer BM, Wesselius LJ. Iron is aregulatory component of human IL-1beta production. Support for regional variability in the lung. Am J Respir Cell Mol Biol 2000; 23(1): 112-9. 
11. Ghio AJ, Hilborn ED, Stonehuerner JG, Dailey LA, Carter $J D$, Richards $J H$, et al. Particulate matter in cigarette smoke alters iron homeostasis to produce a biological effect. Am J Respir Crit Care Med 2008; 178(11): 1130-8.

12. Siedlinski $M$, Tingley D, Lipman PJ, Cho MH, Litonjua AA, Sparrow D, et al. COPDGene and ECLIPSE Investigators. Dissecting direct and indirect genetic effects on chronic obstructive pulmonary disease (COPD) susceptibility. Hum Genet 2013; 132(4): 431-41.

13. Chappell SL, Daly L, Lotya J, Alsaegh A, Guetta-Baranes T, Roca J, et al. The role of IREB2 and transforming growth factor beta-1 genetic variants in COPD: a replication casecontrol study. BMC Med Genet 2011; 12: 24.

14. Castaldi PJ, Cho MH, San José Estépar R, McDonald ML, Laird N, Beaty TH, et al. Genome-wide association identifies regulatory Loci associated with distinct local histogram emphysema patterns. Am I Respir Crit Care Med 2014; 190(4): 399-409.
15. Buhnik-Rosenblau K, Moshe-Belizowski S, Danin-Poleg Y, Meyron-Holtz EG. Genetic modification of iron metabolism in mice affects the gut microbiota. Biometals 2012; 25(5): 883-92.

16. Malhotra R, Olsson H. Immunology, genetics and microbiota in the COPD pathophysiology: potential scope for patient stratification. Expert Rev Respir Med 2015; 9(2): 153-9.

17. Lutz SM, Cho MH, Young K, Hersh CP, Castaldi PJ, McDonald $M$, et al. A genome-wide association study identifies risk loci for spirometric measures among smokers of European and African ancestry. BMC Genet 2015; 16: 138. 